\title{
Pengaruh Kualitas Pelayanan, Pengetahuan Perpajakkan dan Biaya Kepatuhan pada Kepatuhan Wajib Pajak Kendaraan Bermotor
}

\author{
Ni Kadek Metri Tresnalyani ${ }^{1}$ \\ I Ketut Jati ${ }^{2}$ \\ ${ }^{1}$ Fakultas Ekonomi dan Bisnis Universitas Udayana (Unud), Bali, Indonesia \\ email: tresnalyani1996@gmail.com telp: +62 81238706180 \\ ${ }^{2}$ Fakultas Ekonomi dan Bisnis Universitas Udayana (Unud), Bali, Indonesia
}

\begin{abstract}
ABSTRAK
Penelitian ini memiliki tujuan agar mendapatkan bukti empiris mengenai pengaruh kualitas pelayanan, pengetahuan perpajakkan, dan biaya kepatuhan pada kepatuhan wajib PKB di Kantor Bersama SAMSAT Kota Denpasar. Penelitian ini menggunakan semua wajib PKB yang aktif dan terdaftar di Kantor Bersama SAMSAT Kota Denpasar sebagai populasi, dengan sampel yang digunakan sejumlah 100 responden yang dihitung menggunakan rumus Slovin dengan metode accidental sampling. Pengumpulan data dilakukan dengan metode kuesioner dengan teknik analisis data yang digunakan yaitu regresi linier berganda. Hasil dari penelitian ini membuktikanbahwa kualitas playanan dan pengetahuan perpajakkan berpengaruh positif terhadap kepatuhan wajib PKB. Sedangkan biaya kepatuhan berpengaruh negatif pada kepatuhan wajib PKB.

Kata Kunci:Kualitas pelayanan, pengetahuan perpajakkan, biaya kepatuhan, kepatuhan wajib pajak
\end{abstract}

\begin{abstract}
The purpose of this study is to obtain empirical evidence of the effect of service quality, tax knowledge, and compliance costs on compliance of motor vehicle taxpayers in SAMSAT Office Denpasar City. The population in this research is all obligatory PKB active and registered in SAMSAT OfficeDenpasar City, that used 100 sample of responden. The sample was count by Slovin formula with accidental sampling method. The data was collectedby questionnaire method and the data analysis technique used doubled linear regression. This research shows that service quality and tax knowledge have a positive effect on motor vehicle taxpayer compliance. While the cost of compliance has a negative effect on the compliance of motor vehicle taxpayers.

Keywords: Quality of service, tax knowledge, compliance cost, taxpayer compliance
\end{abstract}

\section{PENDAHULUAN}

Pajak memiliki arti yaitu kontribusiwajib pajak yang terutang yang memiliki sifat memaksa dengan tidak mendapatkan kontraprestasi secara langsung. Soemitro dalam (Mardiasmo, 2016: 3) menjelaskan pengertian dari pajak yaitu iuran dari masyarakat untuk kas negara menurut undang-undang dengan tidak memperoleh 
balas jasa secara langsung bias ditunjukkan maupun digunakan untuk mendanaipembangunan nasional. Rusyadi (2009) mendefinisikan pajak sebagai sumber pendanaan yang digunakan untuk menjalankan tanggungjawab negara dalam memecahkan permasalah sosiial, membuatmasyarakat lebih sejahtera dan makmur dan menjadi kontak sosial antar masyarakat dengan pemerintahan.

Jenis pemungutannya, pajak dibagi menjadi dua bagian yaitu pajak pusat dan pajak daerah. Berdasarkan pasal 1 ayat (6) Peraturan Daerah Provinsi Bali Nomor 1 tahun 2011 menjelaskan pajak daerah merupakan kontribusi wajib kepada daerah yang terhutang dengan sifat memaksa berdasarkan undang-undang yang tidak memperoleh imbalan secara langsung dan digunakan untuk keperluan daerah bagi sebesar-besarnya kemakmuran rakyat. Pajak provinsi dibagi menjadi lima jenis pajak, yaitu: Pajak Kendaraan Bermotor (PKB), Bea Balik Nama Kendaraan Bermotor, (BBNKB), Pajak Bahan Bakar Kendaraan Bermotor, Pajak Air Permukaan dan Pajak Rokok.

Menurut Peraturan Daerah Provinsi Bali No. 1 tahun 2011, Pajak Kendaraan Bermotor (PKB) adalah pajak atas kepemilikan ataupun penguasaan kendaraan bermotor. Wajib PKB yaitu orang pribadi, badan ataupun instansi pemerintahan yang mempunyai kendaraan bermotor. Dasar untuk pengenaan PKB dapat dihitung dengan perkalian dari dua unsur pokok yaitu nilai jual kendaraan bermotor dan bobot yang menjelaskan secara relatif kadar kerusakan jalan ataupun pencemaran lingkungan yang diakibatkan oleh penggunaan kendaraan bermotor. 
Berdasarkan Perda Provinsi Bali Nomor 1 tahun 2011 pasal 9 ayat (1) menyatakan PKB yang terutang dipungut pada wilayah daerah tempat kendaraan bermotor tersebut terdaftar. Pembayaran PKB yang terutang dilakukan di Kantor bersama Sistem Administrasi Manunggal dibawah Satu Atap (SAMSAT) (Dharma dan Suardana, 2014). Kantor Bersama SAMSAT Kota Denpasar merupakan ujung tombak dari seluruh kegiatan pembayaran pajak kendaraan bermotor masyarakat kota Denpasar.

Dharma dan Suardana (2014) menyatakan PKB adalah salah satu pajak daerah yang memiliki potensi cukup besar dalam mendanai pembangunan daerah. Pembangunan daerah di setiap kabupaten atau kota salah satunya didanai dari dana yang diperoleh dari pajak kendaraan bermotor, sehingga hal tersebut membuat pemerintah daerah mengoptimalkan pemungutan pajak ini. Berdasarkan data yang diperoleh Dinas Pendapatan Daerah (Dispenda) Provinsi Bali, bahwa pada tahun 2016 PKB memberikan kontribusi terbesar kepada pajakk daerah dibandingkan tahun sebelumnya yaitu sebesar 36,73 persen. Besarnya kontribusi PKB tersebut disebabkan karena semakin meningkatnya jumlah kendaraan bermotor dari tahun ke tahun di Provinsi Bali. Masyarakat menganggap bahwa kendaraan bermotor tidaklah lagi dijadikan sebagai barang mewah, namun sudah merupakan suatu kebutuhan pokok masyarakat untuk melaksanakan aktifitas setiap harinya. Hal ini yang menjadi salah satu faktor dari meningkatnya jumlah kendaraan yang beredar di provinsi Bali.

Jumlah kendaraan yang terdaftar di Provinsi Bali pada tahun 2016 yaitu sebanyak 3.703.042. Kota Denpasar menempati urutan pertama jumlah terbanyak 
dibandingkan kabupaten lain dengan jumlah 1.243.145 kendaraan bermotor. Tabel 1 yang menyajikan jumlah wajib pajak yang membayar PKB dan yang menunggak di Kota Denpasar selama lima tahun terakhir.

Tabel 1.

Wajib Pajak yang Telah Melaksanakan Kewajiban Perpajakkannya dan juga yang Masih Menunggak di Kantor Bersama SAMSAT Kota Denpasar Pada Tahun 2012-2016

\begin{tabular}{cccc}
\hline Tahun & $\begin{array}{c}\text { Unit yang } \\
\text { Terealisasi }\end{array}$ & $\begin{array}{c}\text { Unit yang } \\
\text { Menunggak }\end{array}$ & $\begin{array}{c}\text { Persentase Unit yang Menunggak } \\
(\%)\end{array}$ \\
\hline 2012 & 775.292 & 462 & 0,060 \\
2013 & 938.149 & 836 & 0,089 \\
2014 & 756.730 & 313 & 0,041 \\
2015 & 765.726 & 62 & 0,008 \\
2016 & 748.113 & 66 & 0,009 \\
\hline
\end{tabular}
Sumber: Dinas Pendapatan Daerah Provinsi Bali, 2017 (data diolah)

Berdasarkan tabel 1 dapat dilihat bahwa jumlah wajib PKB yang menunggak dari tahun 2012 ke 2013 mengalami peningkatan yang signifikan sebesar 80,95 persen (374 unit). Pada tahun 2014 dan 2015 wajib pajak yang menunggak mengalami penurunan yaitu sebesar 62,56 persen (523 unit) dan 80,19 persen (251 unit). Namun tahun 2016 jumlah yang menunggak kembali mengalami peningkatan yang tidak signifikan yaitu sebesar 6,54 persen (4 unit). Berdasarkan tabel diatas dapat disimpulkan bahwa jumlah wajib pajak yang menunggak mengalami fluktuasi namun cenderung menurun. Hal tersebut mengindikasikan bahwa tingkat kepatuhan wajib PKB di Kota Denpasar meningkat.

Green (1991) menjelaskan bahwa kepatuhan definisikan menjadi perubahan tindakan yng tak mentaati keperilaku yng mentaati. Lederman (2003) menjelaskan bila wajib pajak melaksanakan kewajibannya dikarenakan 
mennganggapbahwa jika patuh padaperpajakanmerupakan suatu norma.Fronzoni (1999) Kepatuhan dalam hukum pajak mempunyai pengertian umum sebagai melaporkan dan memperhitungkan dengan benar dasar pajak, tepat waktu dalam pengembalian dan dalam membayar jumlah dihitung. Menurut Chau dan Leung (2009) mendefinisikan bahwa apabila kepatuhan dari wajib pajak tidak meningkat makaakan mengancam upaya-upaya yang dilakukanpemerintah untuk mensejahteraan masyarakatnya. Fronzoni (1999) menjelaskan kepatuhan dalam hukum perpajakkanadalah melaporkan dengan benar dasar pajak, menghitung dengan benar kewajiban, tepat waktu dalam pengembalian dan membayar.Maka dari itu, masyarakat harus patuh untuk memenuhi kewajiban perpajakaannya agar pendapatan negara meningkat dan pemerintah dapat mensejahterakan rakyat.

Permasalahan yang paling serius dihadapi oleh para pembuat kebijakan ekonomi salah satunya yaitu meningkat kepatuhan wajib pajak (Torgler, 2005). Menurut Redae dan Sekhon (2017), studi kepatuhan pajak menunjukkan bahwa banyak faktor dampak ekonomi, sosial, psikologis, dan demografis terhadap perilaku kepatuhan pembayar pajak. Faktor-faktor yang diduga dapat mempengaruhi tingkat kepatuhan wajib pajak dalam membayar PKB adalah kualitas pelayanan, pengetahuan perpajakkan, dan biaya kepatuhan.

Berdasarkan Undang-Undang Republik Indonesia No 25 tahun 2011 mengenai pelayanaan publik, pelayanaan adalah rangkaian aktifitas dalam halmemenuhi kebutuhan pelayanan, sesuai dengan peraturan undang-undangatas barang, jasa ataupun pelayanan administrasi yang diberikan oleh pemerintah. Kualitas pelayanan dapat didefinisikan sebagai kemampuan dari suatu organisasi 
dalam memenuhi atau melebihi harapan pelanggan(Parasuraman, et al., 1985). Palda dan Hanousek (2002) menjelaskan bahwa rasa senang maupun puas mengenai pelayanan yang diperoleh dari pemerintah bisamemberikan motivasi dan kepatuhan untuk wajib pajak yang pada akhirnya dapat membuat penerimaan kas negara menjadi meningkat. Maka dari itu kualitas pelayanan yang diberikan oleh pemerintah inilah yang harus selalu diperbaiki dan tingkatkan. Dalam penelitian yang dilakukan oleh Pranata dan Setiawan (2015) menyatakan bahwa kualitas pelayanan berpengaruh positif pada kepatuhan wajib pajak dalam membayar pajak restoran di Dinas Pendapatan Kota Denpasar. Hal yang sama juga dinyatakan dalam penelitian Sanjaya (2015) dan Paramartha (2015) menyatakan bahwa kualitas pelayanan berpengaruh signifikan terhadap kepatuhan wajib pajak.

Pegetahuan di bidang perpajakkan merupakan faktor penting untuk membantu wajib pajak dalam melaksanakan kewajiban perpajakkannya. Richarson (2006) Pengetahuan perpajakkan yaitu wajib pajak tahu mengenai informasi mengenai dasar perpajakkan sehingga wajib pajak mau untuk patuh terhadap peraturan dan ketentuan perpajakkan yang berlaku. Pengetahuan perpajakkan dari seorang wajib pajak dapat diukur melalui pengetahuan dan pemahaman mengenai hak, kewajiban dan tanggungjawab sebagai wajib pajak. Pengetahuan yang dimiliki oleh wajib pajak tentang perpajakkan yang baik maka akan memperkecil terjadinya penggelapan pajak (Palil, 2005). Penelitian yang dilakukan oleh Siregar (2012) dan Sucahyani (2017) menunjukkan bahwa pengetahuan perpajakkan berpengaruh positif dan signifikan, sedangkan dalam 
penelitian yang dilakukan oleh Hardiningsih (2011) dan Damajanti (2015) menunjukkan bahwa pengetahuan perpajakkan berpengaruh negatif pada kepatuhan wajib pajak.

Faktor selain pengetahuan perpajakkan dalam penelitian ini yang dapat mempengaruhi kepatuhan wajib pajak adalah biaya kepatuhan. Menurut Susmita (2015) biiaya kepatuhn pajak yaitu seluruh biaya yang dikorbankan oleh Wajib Pajak bila akan melakukan pembayaran pajak. Slemrod (1991) menjelaskan keinginan dalam mentaati peraturan-peraturan perpajakkan tidak bisaterpenuhi jikawajib pajak menghadapi kesulitan dalam menguasai peraturan perpajakkan yang disebabkan karena rumitnya dan multitafsir yang melekat pada peraturan perpajakkan. Wajib pajak sudah mengusahakanuntuk meningkatkan kepatuhannya dalam melaksanakan kewajibannya seperti ketentuan undang-undang perpajakan yang telah ditetapkan, maka wajib pajak mengharapkan supayabiaya yang dikeluarkan bisa sekecil mungkin jika akan melaksanakan kewajiban perpajakkannya.Tetapi bila jumlah biaya kepatuhan pajak yang harus dikorbankan lebih besar dari ekspektasi wajib pajak, maka akan timbul potensi dalam wajib pajak akan menjadi kurang patuh dalam melaksanakan kewajiban perpajakkannya (Susmita, 2016).Kelompok biaya kepatuhan pajak terbagi atas tiga jenis biaya (Fuadi, 2013) diantaranya yaitu: 1)Direct money cost, 2) Time cost, dan 3) Psychological cost. Penelitian yang dilakukan oleh Anggadewi (2015) dan Syarifudin (2016) menyatakan bahwa biaya kepatuhan mempengaruhi kepatuhan wajib pajak secara signifikan. Namun berdasarkan penelitian Fuadi dan 
Mangoting (2013) dan Susmita (2015) menyatakan hal yang sebaliknya yaitu biaya kepatuhan berpengaruh negatif terhadap kepatuhan wajib pajak.

Penelitian ini kembali dilakukan karena disebabkan adanya perbedaan hasil-hasil penelitian sebelumnya. Hal-hal yang membedakan penelitian ini dengan penelitian-penelitian sebelumnya adalah objek penelitian, lokasi penelitian, dan tahun penelitian. Berdasarkan hal tersebut peneliti merasa perlu meneliti kembali kepatuhan wajib pajak kendaraan bermotor yang diduga dapat dipengaruhi oleh beberapa faktor, maka dari pokok permasalahan penelitian ini berjudul "Pengaruh Kualitas Pelayanan, Pengetahuan Perpajakan, dan Biaya Kepatuhan pada Kepatuhan Wajib Pajak Kendaraan Bermotor di Kantor Bersama SAMSAT Kota Denpasar".

Berdasarkan uraian di atas, maka rumusan masalah yang diangkat adalah 1) Apakah kualitas pelayanan mempengaruhi kepatuhan wajib pajak dalam membayar PKB di Kantor Bersama SAMSAT Kota Denpasar? Apakah pengetahuan perpajakkan mempengaruhi kepatuhan wajib pajak dalam membayar PKB di Kantor Bersama SAMSAT Kota Denpasar? Apakah biaya kepatuhan mempengaruhi kepatuhan wajib pajak dalam membayar PKB di Kantor Bersama SAMSAT Kota Denpasar?

Terdapat beberapa tujuan dari penelitian ini yaitu: 1) Memperoleh bukti empiris mengenai kualitas pelayanan mempengaruhi kepatuhan wajib pajak dalam membayar PKB di Kantor Bersama SAMSAT Kota Denpasar. 2) Untuk memperoleh bukti empiris mengenai pengaruh pengetahuan perpajakkan pada kepatuhan wajib pajak dalam membayar PKB di Kantor Bersama SAMSAT Kota 
Denpasar. 3) Agar memperoleh bukti empiris mengenai pengaruh biaya kepatuhan pada kepatuhan wajib pajak dalam membayar PKB di Kantor Bersama SAMSAT Kota Denpasar.

Manfaat yang dapat diperoleh dari penelitian ini ada dua yaitu manfaat teoritis dan manfaat praktis. Secara teoritis hasil penelitian ini nantinya dapat berfungsi untuk menambah pengetahuan dalam bidang perpajakkan mengenai kepatuhan wajib pajak kendaraan bermotor serta dapat memberikan bukti empiris atas theory of planned behavior. Selain itu, hasil penelitian ini sangat diharapkan dapat digunakan oleh peneliti selanjutnya sebagai referensi. Secara praktis hasil dari penelitian yang dilakukan bias dijadikan sebagai masukan dan dapat menambah refferensi untuk pemerintah dan wajiib pajk untuk meneliti lebih lanjut mengenai faktor- faktor wajib pajak yang mempengaruhi kepatuhan wajib pajak kendaraan bermotor.

Penelitian tentang kepatuhan wajib pajak dapat dilihat dari segi psikologis wajib pajak tersebut (Feld and Frey, 2002). Theory of Planned Behavior (TPB) digunakan jika mengkaji kajian dalamhal psikologis tentang perilaku kepatuhan yang dapat dipengaruhi beberapa faktor. Mustikasari (2007) mengemukakan bahwa jika perilaku-perilaku yang ditimbulkan olehseseorang muncul dikarenakan terdapat niat untuk berperilaku, niat yang muncul untuk bertingkahlaku tersebut disebabkan oleh tiga faktor:

Behavioral beliefs didefinisikan sebagai keyakinan dari suatu orang atas hasil yang didapatkan dari sebuah prilaku dan evaluasii dari hasil itu.Kyakinan maupun evaluasi dari hasil tersebutselanjutnya dapat dibentuk menjadi variable 
sikap. Normative beliefs didefinisikan sebagai keyakinan mengenai harapan normative individu lain yang dijadikan sebagaipanutan dan sebagai motivsi dalam memenuhi harapan tersebut. Harapan normative tersebut nantinya akandapat dibentuk menjadi variabel norma subjekti. Control beliefs didefinisikan sebagai suatu keyakinan seseorang mengenai keberadaan daribeberapa hal yang dapat meningkatkan ataupun menurunkanperilaku yang akan ditampilkan dan persepsinya mengenai seberapa kuatnya hal-hal yang dapat meningkatkan dan menurunkan niat berperilakunya (perceived power).

Apabila teori tersebut dikaiitkan dengan penelitian yang dilakukan ini, maka Teory of Planed Behavior (TPB) dapat dinyatakan rilevan dalam menerangkan perilaku-perilaku dari wajib pajak dlam melaksanakan kewajiban perpajakkannya. Seorang wajib pajak dalam menentukan perilakunya untukmematuhi ataupun tidak mematuhi dalam melaksanakan kewajiban perpajakkannya dpengaruhi oleh rasionaltas bila mempertimbankan manfaat yang akan ditimbulkan oleh pajak dan pngaruh dari lingkungan sekitar yang berhubungan dengan membentuk normaa subjektf yang mempengaruhi keputusan perilaku.

Berdasarkan teory of planed behavioral dijelaskan bahwa salah satu faktor munculnya niat berprilaku adalah normative beliefs yaitu individu akan memiliki keyakinan tentang harapan normatif dari orang lain dan motivasi untuk memenuhi harapan tersebut. Menurut Ancok (dalam Laksono dan Ardiyanto 2011), aparat pajak dituntut untuk memberikan pelayanan yang ramah, adil, dan tegas setiap saat kepada wajib pajak serta dapat memupuk kesadaran masyarakat tentang 
tanggung jawab membayar pajak. Harapan dari kualitas pelayanan yang baik adalah wajib pajak dapat memperoleh kemudahan dalam menyelesaikan kewajiban pajaknya. Pelayanan yang berkualitas didefinisikan sebagai suatu pelayanan yang dapat menimbulkanrasa puas bagikonsumen dan selalu dalam batas standar pemenuhan harapan layanan dan harus selalu wajib dilaksanakan. Apabila didefinisikan secara sederhana kualitas dapat diartikan sebagai suatu kondisidinamis yang berhubungan dengan produk, jasa, proses maupun lingkungan yang dapat memenuhi atau melebihi harapan dari pihak yang menginginkannya (Alabede et al., 2011).

Hasil Penelitian yang diperoleh oleh Sanjaya (2014)) menunjukkan bila kualitas pelayanan mempengaruhi secara signifikan pada kepatuhan wajib pajak. Hasil tersebut didukung oleh penelitian Putri dan Jati (2013), Utama (2013), Pranata dan Setiawan (2015), dan Pramartha (2015) yang menunjukkan bila kualitas atas pelayanan yang diberikan mempengaruhi kepatuhan wajib pajak secara positif dan signifikan. Berdasrkan hal tersebut, oleh karna itu dapat dirumuskan hipotesis pertama yaitu:

$\mathrm{H}_{1} \quad$ : Kualitas pelayanan berpengaruh positif pada kepatuhan wajib pajak kendaraan bermotor

Pengetahuan yang dimiliki oleh wajib pajak tentangpajak jika dikaitkan dengan theory of planned behavior maka pengetahuan perpajakkan merupakan bagian dari persepsi wajib pajak dalam menentukan perilakunya (perceived control behavior) dalam mematuhisaat melaksanakan kewajibannya. Jika pengetahuan dalam halperpajkkan yang dimiliki oleh wajib pajak tinggi maka 
akan membuat wajib pajak berperilaku lebih baik dan sesuia dengan peraturan perpajakkan, sehingga tingkat kepatuhan yang dimiliki dalam membayar pajak akan tinggi juga.Berdasarkan penelitian yang dilakukan oleh Fikriningrum (2012) menjelaskan bahwa dalam memenuhi kewajiban dalam membayar pajak dipengaruhi olrh pengetahuan dan pemahaman wajib pajak mengenai peraturan perpajakkan.

Penelitian yang dilakukan oleh Utomo (2011) mengemukakan bahwa pengetahuan perpajakkan berpengaruh positif dan signifikan pada kepatuhan wajib pajak. Penelitian tersebut sejalan dengan hasil dari penelitian yang dilakukan oleh Siregar (2012), Susilawati dan Budiartha (2013), Rusmayani dan Supadmi (2017), dan Sucahyani (2017) yang juga menyatakan bahwa pengetahuan perpajakan berpengaruh positif dan signifikan terhadap kepatuhan wajib pajak. Berdasarkan penjelasan tersebut, maka diambil hipotesis sebagai berikut:

$\mathrm{H}_{2}$ : Pengetahuan perpajakan berpengaruh positif pada kepatuhan wajib pajak kendaraan bermotor

Berdasarkan theory of planned behavioral, Biaya kepatuhan terkait dengan perceived behavioral control. Sejumlah biaya yang harus dikorbankan oeh wajib pajak merupakan definisi dari biayaa kepatuhan dalam memenuhi kewajiban dan memperoleh hak perpajakkannya.Dikaitkan dengan biaya kepatuhan, Theory of Planned behaviormenjelaskan bila wajib pajak yang mengeluarkan dana yang besar dan memberatkan saat akan melaksanakan kewajibannya akan cenderung melakukan tax evation namun bila dana yang harus dikeluarkan 
tidakmembebankan, maka wajib pajak akan lebih menghindari tax evation (Kurnawati,2014).

Penelitian yang dilakukan oleh Fuadi (2013) menyatakan bahwa biaya kepatuhan berpengaruh negatif terhadap kepatuhan wajib pajak. Hal tersebut didukung oleh penelitian yang dilakukan oleh Susmita (2015). Berdasarkan penjelasan tersebut, maka diambil hipotesis sebagai berikut:

$\mathrm{H}_{3} \quad$ : Biaya kepatuhan berpengaruh negatif pada kepatuhan wajib pajak kendaraan bermotor.

\section{METODE PENELITIAN}

Pendekatan kuantitatif digunakan dalam melakukan penelitian ini dengn berbentuk asosiatiif dengan tipe kuasalitas (Sugiyono, 2015: 13). Kantor bersama SAMSAT Kota Denpasar dijadikan lokasi untuk melakukan penelitian. Objek dari penelitian yang dilakukanyaitu kepatuhan wajib PKB yang diduga dapat dipengaruhi kualitas pelayanan, pengetahuan perpajakkan, dan biaya kepatuhan. Variabel dependen dalam penelitian ini adalah Kepatuhan Wajib Pajak (Y). Kepatuhan wajib pajak diukurdengan mengadopsi indikator yang digunakan Susilawati (2013).

Variabelbebas dalam penelitian ini adalah kualitas pelayanan $\left(\mathrm{X}_{1}\right)$ diukur dengan mengadopsi indikator yang digunakan Febriyanti dan Setiawan (2017), Pengetahuan perpajakan $\left(\mathrm{X}_{2}\right)$ diukur dengan mengadopsi indikator yang digunakan Utomo (2011), serta Biaya kepatuhan $\left(\mathrm{X}_{3}\right)$ diukurdengan mengadopsi indikator yang digunakanSusmita (2015). 
Seluruh wajib PKB yang aktif pada Kantor Bersama SAMSAT Kota Denpasar menjadi populasi dalam penelitian ini yaitu sejumlah 748.113 wajib pajak. Sampel yang akan diambil dari populasi tersebut menggunakan metode accidental sampling, yang merupakan metode berdasarkan kebetulan yaitu siapapun wajib PKB yang secarakebetulan ditemuioleh peneliti bisa dijadikan sampel apabila wajin PKB yang kebetulan ditemui tersebut dinilaitepat sebagai sumber data.Penentuan ukuran sampel Wajib PKB di Kota Denpasar digunakan rumus Slovin. Melalui perhitungan menggunakan rumus Slovin, jumlah sampel yang akan digunakan dalam penelitian ini adalah sebanyak 100 sampel Wajib Pajak Kendaraan Bermotor yang aktif dan terdaftar sebagai Wajib PKB di Kantor Bersama SAMSAT Kota Denpasar. Penelitian ini menggunakan kuesioner yang diberikan langsung kepada responden oleh peneliti dengan menggunakan skala 4 poin. Adapun analisis data dalam penelitian ini menggunakan beberapa uji yaitu:

Pertama Instrumen Penelitian yang terdiri dari : 1) Uji Validitas untuk mengukur sejauh mana variabel yang digunakan benar-benar mengukur apa yang seharusnya diukur. Valid berarti instrument tersebut dapat digunakan untuk mengukur apa yang seharusnya diukur (Sugiyono, 2015: 172), dan 2) Uji Reabilitas data, data disebut reliabel apabila instrumen yang digunakan lebih dari sekaliuntuk mengukuri objek yang sama maka dapat memperoleh informasi yang tidak berbeda (Sugiyono, 2015: 174). Hasil uji reliabiliitas dengan bantuan SPSS nantinya akan menghasilkan Cronbach Alpha. Dikatakan reliabel apabila hasil dari Cronbach Alpha memiliki nilai $>0,70$. Kedua Analisis Statistik Deskriptifdipergunakan untuk menggambarkan atau menjelaskan suatu data pada 
variabel penelitian. Analisis statistik deskriptif dilihat berdasarkan nilai rata-rata (mean), standar deviasi, nilai maksimum, dan nilai minimum.

Keempat Uji Asumsi Klasik bertujuan untuk menghasilkan model regresi yang baik yang terdiri dari : 1) Uji Normalitas, uji normalitas yang dilakukan dalam penelitian ini menggunakan One Sample Kolmogorov Smirnof Test dengan mencari nilai $p$-value, 2) Uji Heteroskedastisitas bertujuan menguji apakah dalam model regresi terjadi ketidaksamaan varians dari residual satu pengamatan ke pengamatan yang lain, dan 3) Uji Multikolinearitas bertujuan untuk menguji apakah dalam model regresi terdapat korelasi antar variabel bebas (independen).

Model regresi yang baik adalah tidak adanya korelasi di antara variabel independen (Ghozali, 2013: 103).Uji Kelayakan Model (Uji F)Apabila nilai pvalue dari $\mathrm{F}>\alpha$ sebesar 0,05 , hal ini dapat diartikan bahwa model penelitian tidak layak digunakan, sedangkan apabila nilai $\mathrm{p}$-value dari $\mathrm{F} \leq \alpha$ sebesar 0,05 , hal ini dapat diartikan bahwa model penelitian ini layak untuk digunakan. Uji Koefisien Determinasi $\left(\mathrm{R}^{2}\right)$ untuk mengetahui apakah model penelitian mampu menjelaskanvariasi variable bebas. Uji Hipotesis (Uji t)dilakukan untuk menunjukkan seberapa jauh pengaruh satu variabel independen secara parsial dapat menerangkan variabel dependen.

Analisis Regresi Linier Berganda memiliki tujuanuntuk memperkirakan perubahan respon pada variabel dependen terhadap variabel independen (Hair et al., 1995). Penelitian ini memiliki persamaan regresi sebagai berikut :

$$
\mathrm{Y}=\alpha+\beta_{1} \mathrm{X}_{1}+\beta_{2} \mathrm{X}_{2}+\beta_{3} \mathrm{X}_{3}+\mathrm{e}
$$




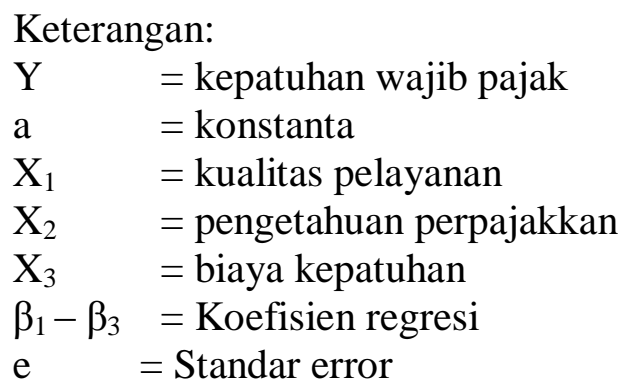

\section{HASIL DAN PEMBAHASAN}

Sampel yang akan diambil dari populasi tersebut menggunakan metoda acidental sampling. Metoda tersebut merupakan metode yang dilakukan atas dasar kebetulan yaitu siapapunwajib PKB yang tanpa sengaja ditemuioleh penelti bisa dijadikan sample apabila wajin PKB yang tanpa sengaja ditemui tersebut diangkaptepat menjadi responden.Penentuan ukuran sampel Wajib PKB di Kota Denpasar akan digunakan rumus Slovin, sehingga didapatkan 100 sampel yang dapat dijadikan sebagai respnden dalam penelitian.Sampel terdiri dari 100 responden Wajib PKB di Kantor Bersama SAMSAT Kota Denpasar. Distribusi kuesioner dalam penelitian ini secara lengkap ditunjukkan pada table dibawah ini:

Tabel 2.

Distribusi Kuesioner

\begin{tabular}{lcc}
\hline \multicolumn{1}{c}{ Item } & Jumlah & Presentase (\%) \\
\hline Kuesioner yang dibagikan & 100 & $100 \%$ \\
Kuesioner yang tidak diisi & 0 & $0 \%$ \\
Kuesioner yang tidak diisi dengan lengkap & 0 & $0 \%$ \\
Kuesioner yang dapat diolah & 100 & $100 \%$ \\
\hline Tingkat Pengembalian Kuesioner (respon rate) & $: 100 / 100 \times 100 \%=100 \%$ & \\
Kuesioner yang digunakan (useable respon rate) & $: 100 / 100 \times 100 \%=100 \%$ & \\
\hline Sumber :Data diolah, 2018 & &
\end{tabular}


Berdasarkan Tabel 2, dapat ditarik kesimpulan yaitu kuesioner yang disebar kepada wajib pajak sebanyak 100 eksemplar. Kuesioner yang telah beredar tersebut memiliki tingkat pengembalian sebesar 100 persen, maka dari itu kuesioner yang dapat digunakan sebagai sumber data yaitu sebanyak 100 kuesioner dari seluruh kuesioner yang tersebar.

Berikut ini merupakan hasil dan pembahasan dari Analisis Statistik Deskriptif, Uji Validitas Data, Uji Reabilitas Data, , Uji Asumsi Klasik, danAnalisis Regresi Linier Beganda.

Tabel 3.

Hasil Statistik Deskriptif

\begin{tabular}{lrrrrr}
\hline & N & Minimum & Maximum & Mean & $\begin{array}{c}\text { Std. } \\
\text { Deviation }\end{array}$ \\
\hline Kualitas Pelayanan $\left(\mathrm{X}_{1}\right)$ & 100 & 36,00 & 71,00 & 51,9700 & 6,57890 \\
Pengetahuan Perpajakan $\left(\mathrm{X}_{2}\right)$ & 100 & 5,00 & 20,00 & 15,5300 & 2,20401 \\
Biaya kepatuhan $\left(\mathrm{X}_{3}\right)$ & 100 & 8,00 & 20,00 & 13,5800 & 2,26604 \\
Kepatuhan Wajib Pajak $(\mathrm{Y})$ & 100 & 4,00 & 16,00 & 13,7700 & 1,94809 \\
\hline
\end{tabular}

Sumber: Data diolah, 2018

Berdasarkan Tabel 3, dapat dilihat bahwa statistik deskriptif dari seluruh variabel-variabel yang diteliti dapat dideskripsian yaitu sebgai berikut: Nilai terendah (minimum) untuk variabel kualitas pelayanan sebesar 36,00, nilai tertinggi (maximum) sebesar 71,00 dan nilai rata-rata (mean) sebesar 51,97. Nilai standar deviasi variabel kualitas pelayanan sebesar 6,57 memiliki arti bahwa terjadi perbedaan nilai dari kualitas pelayanan terhadap nilai minimum sebesar 6,57. Nilai terendah (minimum) untuk variabel pengetahuan perpajakkan sebesar 5,00, nilai tertinggi (maximum) sebesar 20,00 dan nilai rata-rata (mean) sebesar 15,53. Nilai standar deviasi variabel Pengetahuan perpajakkan sebesar 2,20 yang 
memiliki arti bahwa terdapat kesenjangan nilai variabel pengetahuan perpajakkan terhadap nilia minimun sebesar 2,20. Nilai terendah (minimum) untuk variabel Biaya Kepatuhan sebesar 8,00, nilai tertinggi (maximum) sebesar 20,00 dan nilai rata-rata (mean) sebesar 13,58. Nilai standar deviasi variabel biaya kepatuhan sebesar 2,26 yang memiliki arti bahwa terdapat perbedaan nilai variabel biaya kepatuhan terhadap nilai rata-rata 2,26. Nilai terendah (minimum) untuk variabel kepatuhan wajib pajak sebesar 4,00, nilai tertinggi (maximum) sebesar 16,00 dan nilai rata-rata (mean) sebesar 13,77. Nilai standar deviasi variabel kepatuhan wajib pajak sebesar 1,94yang memiliki arti bahwa perbedaan nilai variabel kepatuhan wajib pajak terhadap nilai rata-rata sebesar 1,94. Hasil uji asumsi klasik ini disajikan sebagai berikut.

Tabel 4.

Rekapitulasi Hasil Uji Asumsi Klasik

\begin{tabular}{ccccc}
\hline \multirow{2}{*}{ Variabel } & \begin{tabular}{c} 
Normalitas \\
\cline { 2 - 5 }
\end{tabular} & \multicolumn{2}{c}{ Multikolinearitas } & Heteroskedastisitas \\
\hline Asymp. Sig. & Tolerance & VIF & Sig. \\
\hline Kualitas Pelayanan & & 0,932 & 1,073 & 0,672 \\
Pengetahuan Perpajakkan & 0,708 & 0,933 & 1,072 & 0,171 \\
Ukuran Perusahan & & 0,996 & 1,004 & 0,783 \\
\hline
\end{tabular}

Sumber:Data diolah, 2018

Pada tabel 4 terlihat bahwa hasil yang diperoleh dari uji normalitas menyatakan jika nilai Asymp. Sig. (2-tailed) sebesar 0,708 lebih besar dari 0,05. Berdasarkan hal tersebut maka data dalam penelitian yang dilakukan berdistribusi normal. Hasil dari uji heteroskedastisitas menunjukkan bahwa seluruh variabel independen dari modiel regeresi yang digunakan memiliki nilai signifikans> 0,05. Hasil tersebut memiliki arti yaitu model regresi dalam penelitian ini tidk terdapat 
gejala heteroskedastitas. Hasil dari uji multikolinearitas persaman regeresi penelitian ini menmbuktikan jika variabel independen mempunyai nilai toleran lebih besar dari 0,10 dan nilai VIF lebih kecil dari 10. Maka dari itu dapat disimpulkan dalam model regresi dari penelitian ini tidak adanya multikolinearitas.

Tabel 5.

Analisis Regresi Linier Berganda

\begin{tabular}{|c|c|c|c|c|c|}
\hline \multirow[t]{2}{*}{ Variabel } & \multicolumn{2}{|c|}{$\begin{array}{l}\text { Unstandardized } \\
\text { Coefficients }\end{array}$} & \multirow{2}{*}{$\begin{array}{c}\text { Standardized } \\
\text { Coefficients } \\
\text { Beta }\end{array}$} & \multirow[t]{2}{*}{$\mathbf{t}$} & \multirow[t]{2}{*}{ Signifikansi } \\
\hline & B & Std. Eror & & & \\
\hline (Constant) & 8,128 & 1,574 & & 5,165 & 0,000 \\
\hline Kualitas Pelayanan & 0,064 & 0,021 & 0,243 & 3,014 & 0,003 \\
\hline $\begin{array}{l}\text { Pengetahuan } \\
\text { Perpajakan }\end{array}$ & 0,352 & 0,064 & 0,444 & 5,516 & 0,000 \\
\hline Biaya Kepatuhan & $-0,230$ & 0,060 & $-0,298$ & -3831 & 0,000 \\
\hline Adjusted $R$ Square & & & 0,402 & & \\
\hline F Hitung & & & 23,222 & & \\
\hline Signifikansi F & & & 0,000 & & \\
\hline
\end{tabular}

Sumber :Data diolah, 2018

Berdasarkan Tabel 5 dapat disusun persaman regresi sebagai berikut :

$$
\mathrm{Y}=8,128+0,064 \mathrm{X}_{1}+0,352 \mathrm{X}_{2}-0,230 \mathrm{X}_{3}+\mathrm{e}
$$

Konstanta dari persamaan regresi dalam penelitian ini yaitu sebesar 8,128yang membuktikanjika variabel independen(kualitas pelayanan, pengetahuan perpajakkan dan biaya kepatuhan) diasumsikkan tetap (konstan) maka nilai variabel dependen (kepatuhan wajib pajak) yaitu sebesar 8,128 satuan. Nilai Koefisien regresi dari variabel kualitas pelayanan sebesar 0,064. Hasil tersebut bermakna bahwa apabila kualitas pelayanan mengalami peningkatan satu satuan, maka kepatuhan wajib PKB dalam membayar pajakmeningkat sebesar 0,064 
satuan dengan asumsi variabel lainnya konstan. Nilai Koefisien regresi dari variabel pengetahuan perpajakkan sejumlah 0,352 . Hasil tersebut bermakna bila pengetahuan perpajakan meningkat satu satuan, maka kepatuhan wajib pajak dalam membayar pajak meningkat sebesar 0,352 satuan dengan asumsi variabel lainnya konstan. Nilai Koefisien regresi dari variabel biaya kepatuhan sebesar 0,230. Hal ini bermakna bahwa apabila biaya kepatuhan meningkat satu satuan, maka kepatuhan wajib pajak dalam membayar pajak menurun sebesar 0,230 satuan dengan asumsi variabel lainnya konstan.

Nilai sig $\mathrm{F}$ sebesar $0,000<0,05$ maka disimpulkan variable bebas mempengaruhi variable terikat secara serempak (simultan). Maka kesimpulannya yaitu model regresi tersebut dinyatakan layak bila ditliti. Nilai adjusted $R^{2}$ sebesar 0,402 ini memiliki arti perubahan yang terjadi pada kepatuhan wajib PKB dapat dijelaskan oleh kualitas pelayanan $\left(\mathrm{X}_{1}\right)$, pengetahuan perpajakkan $\left(\mathrm{X}_{2}\right)$, dan biaya kepatuhan $\left(\mathrm{X}_{3}\right)$ sebesar 40,2 persen, sedangkan 59,8 persen sisanya dijelaskan oleh faktor lain diluar dari model penelitian.

Berdasarkan rumusan hipotesis pertama $\left(\mathrm{H}_{1}\right)$ menyatakan bahwa kualitas pelayanan berpengaruh positif pada kepatuhan wajib pajak kendaraan bermotor. Hasil dari perhitungan menggunakan Uji Regresi Linier Berganda diketahui jika aaanilai $\beta 1$ adalah 0,064 dan signifikansi nilai t sebesar 0,003 , ini memiliki arti hasil yang didapatyaitu kurang dari 0,05. Disimpulkan bahwa kualitas pelayanan berpengaruh positif pada kepatuhan wajib pajak kendaraan bermotor maka hipotesis pertama diterima. 
Berdasarkan penemuan tersebut, maka dapat digambarkan bahwa kualitas pelayanan memiliki peran dalam menentukan kepatuhan wajib PKB di Kantor Bersama SAMSAT Kota Denpasar. Hasil yang diperoleh konsisten dengan hasil penelitian Sanjaya (2014), Putri dan Jati (2013), Utama (2013), Pranata dan Setiawan (2015), dan Pramartha (2015) yang mengatakan bahwa kualitas pelayanan berpengaruh positif pada kepatuhan wajib pajak.

Berdasarkan rumusan hipotesis kedua $\left(\mathrm{H}_{2}\right)$ menyatakan bahwa pengetahuan perpajakkan berpengaruh positif pada kepatuhan wajib pajak kendaraan bermotor. Berdasarkan hasil perhitungan menggunakan Uji Regresi Linier Berganda diketahui bahwa nilai $\beta_{2}$ adalah 0,352 dan signifikansi nilai t sebesar 0,000 , hasil tersebut berarti bahwa angka yang dihasilkan lebih kecil dari nilai $\alpha$ yaitu 0,05 . Maka dari itu dinyatakan hipotesis kedua yaitu pengetahuan perpajakan berpengaruh positif pada kepatuhan wajib PKB diterima.

Penemuan tersebut, oleh karena itu dapat digambarkan bahwa pengetahuan perpajakan memiliki peran dalam menentukan kepatuhan wajib PKB di Kantor Bersama SAMSAT Kota Denpasar. Hasil yang diperoleh konsisten dengan penelitian Utomo (2011), Siregar (2012), Susilawati dan Budiartha (2013), Rusmayani dan Supadmi (2017), dan Sucahyani (2017) menyatakan pengetahuan perpajakkan memiliki pengaruh positif terhadap kepatuhan wajib pajak.

Berdasarkan rumusan hipotesis ketiga $\left(\mathrm{H}_{3}\right)$ menyatakan bahwa biaya kepatuhan berpengaruh negatif pada kepatuhan wajib pajak kendaraan bermotor. Berdasarkan hasil perhitungan Uji Regresi Linier Berganda, diperoleh nilai $\beta 3$ adalah -0,230 dan signifikansi nilai t sebesar 0,000 yang memiliki arti bila angka 
dari hasil yang didapatyaitu $\alpha<0,05$. Hal tersebut berarti hipotesis ketiga yang menyatakan bahwa biaya kepatuhan berpengaruh negatif pada kepatuhan wajib pajak kendaraan bermotor diterima.

Berdasarkan penemuan tersebut, maka dapat digambarkan bahwa biaya kepatuhan memiliki peran dalam menentukan kepatuhan wajib PKB di Kantor Bersama SAMSAT Kota Denpasar. Hasil penelitian ini konsisten dengan penelitian Fuadi (2013) yang menyatakan bahwa biaya kepatuhan berpengaruh negatif terhadap kepatuhan wajib pajak. Hal tersebut sama seperti penelitian yang dilakukan oleh Susmita (2015) yang menyatakan bahwa biaya kepatuhan berpengaruh negatif terhadap kepatuhan wajib pajak.

Penelitian ini terdiri dari dua jenis implikasi, yaitu implikasi teoritis dan implikasi praktis. Adapun implikasi teoritis dalam penelitian ini yaitu dapat membuktikan teori yang digunakan yaitu Theory of Planned Behavior yang menjelaskan perilaku yang ditimbulkan oleh wajib pajak muncul karena adanya niat untuk berperilaku patuh dalam membayar pajak. Penelitian ini juga menambah referensi, informasi, wawasan, dan membantu meningkatkan tingkat pemahaman yang lebih luas mengenai kualitas pelayanan, pengetahuan perpajakan, dan biaya kepatuhan pada kepatuhan wajib PKB.

Implikasi praktis dalam penelitian ini bagi Kantor Bersama SAMSAT Kota Denpasar adalah untuk lebih memaksimalkan kualitas pelayanan dengan cara memperbaiki sisitem administrasi perpajakkan. Hasil yang didapat dari penelitian yang dilakukanbias dijadikan solusi dari masalah-masalah yang terjadi pada kepatuhan wajib PKB di Kantor Bersama SAMSAT Kota Denpasar. Hasil 
yang didapat dari penelitian yang dilakukan juga bisadijadikan masukan-masukan maupun dapat digunakan untuk menambah referensi-referensi kepada pemerintah dan wajib pajak untuk mencari tahu lebih lanjut mengenai faktor- faktor wajib pajak yang dapat mempengaruhi kepatuhan wajib PKB. Penelitian ini juga menambah referensi, informasi, wawasan, dan memberikan pemahaman yang lebih luas berkaitan dengan kaulitas playanan, pengetahuan perpajakkan, dan biaya kepatuhan terhadap kepatuhan wajib PKB. Sehingga penelitian ini dapat membantu akademisi dan peneliti selanjutnya dalam memberikan informasi dan bahan referensi mengenai kualitas pelayanan, pengetahuan perpajakkan, dan biaya kepatuhan pada kepatuhan wajib pajak.

\section{SIMPULAN}

Adapun penelitian ini dilakukan bertujuan agar mengetahui dan membuktikan pengaruh kaulitas pelayannan, pengetahuan perpajakkan, dan biaya kepatuhan pada kepatuhan wajib PKB di Kantor Bersama SAMSAT Kota Denpasar. Berdasarkan hasil analisis data yang menggunakan teknik analisis linier berganda dan pembahasan pada bab sebelumnya, maka dapat ditarik kesimpulan sebagai berikut:

Berdasarkan hasil penelitian dan pembahasan maka dapat ditarik kesimpulan antara lain : 1) Kualitas pelayanan berpengaruh positif pada kepatuhan wajib pajak kendaraan bermotor di Kantor Bersama SAMSAT Kota Denpasar. Hal ini menunjukkan bahwa semakin meningkat kualitas pelayanan yang diberikan oleh petugas maka semakin meningkatkan kepatuhan wajib pajak kendaraan bermotor dalam membayar pajak kendaraan bermotor. 2) Pengetahuan 
perpajakkan berpengaruh positif pada kepatuhan wajib pajak kendaraan bermotor di Kantor Bersama SAMSAT Kota Denpasar. Hasil tersebutmenyatakanbila semakin meningkatnya pengetahuan perpajakan yang dimiliki oleh Wajib Pajak maka semakin meningkatkan kepatuhan wajib pajak kendaraan bermotor dalam membayar pajak kendaraan bermotor. 3) Biaya kepatuhan berpengaruh negatif pada kepatuhan wajib pajak kendaraan bermotor di Kantor Bersama SAMSAT Kota Denpasar. Hal ini menunjukkan bahwa semakin meningkat biaya kepatuhan maka kepatuhan wajib pajak dalam membayar pajak semakin menurun.

Beberapa saran dalam penelitian ini antara lain :1) Kualitas pelayanan yang diberikan oleh petugas dalam memberikan pelayanan sudah baik, tetapi pelayanan tersebut sebaiknya perlu ditingkatkan. Salah satunya melalui pemberian informasi yang dibutuhkan secara jelas. 2) Pengetahuan Perpajakan di Kota Denpasar perlu ditingkatkan untuk menambah pengetahuan perpajakan yang dimiliki oleh seorang Wajib Pajak untuk memenuhi kewajiban perpajakkannya. Hal ini bisa dilakukan dengan cara melakukan sosialisasi perpajakan untuk memberikan pengetahuan perpajakan sehingga dapat meningkatkan kesadaran wajib pajak. 3) Biaya kepatuhan yang harus dikeluarkan oleh wajib pajak untuk memenuhi kewajibannya tidak terlalu besar, namun pemerintah diharapkan untuk dapat meminimalkan biaya yang harus dikeluarkan oleh wajib pajak selain pajak terutang. Hal tersebut sebaiknya dilakukan oleh pemerintah untuk meminimalisir timbulnya suatu potensi kepatuhan dari wajib pajak berkurang. 4) Bagi wajib pajak khususnya wajib pajak kendaraan bermotor diharapkan lebih sadar untuk melaksanakan kewajiban perpajakkannya agar dapat meningkatkan penghasilan 
Pendapatan Asli Daerah. Wajib pajak diharapkan lebih aktif untuk mencari tahu mengenai peraturan perpajakan khususnya Pajak Kendaraan Bermotor dan tata cara pembayaran pajak kendaraan bermotor.

\section{REFERENSI}

Alabede, James O., et al. 2011. Determinants of Tax Compliance Behavior: A Proposed Model for Nigeria. International ResearchJournal of Finance and Economiic, 78, pp.121-136.

Anggadewi, Anisa. 2015. Pengaruh Pemahaman Pajak dan Biaya Kepatuhan pada Tingkat Kepatuhan Wajib Pajak. Skripsi. Program Studi Akuntansi Fakultas Ekonomi Univeristas Wdiyatama.

Chau, G. and Patrick Leung. 2009. ACritical Review of Fisher Tax Compliance Model. Journal of Acconting an Taxation, 1(2), pp.34-40.

Damajanti, Anita. 2015. Pengaruh Pengetahuan terhadap Kepatuhan Wajib Pajak Perorangan di Kota Semarang. Jurnal Dinamika Sosbud, 17(2), hal.12-28.

Dharma, Gede P. E. dan K. Alit Suardana.2014.Pengaruh Ksadaran Wajiib Pajak, Sosialisasi Perpajakan, Kualitas Pelayanan Pada Kepatuhan Wajib Pajak dalam Membayar Pajak Kendaraan Bermotor (PKB) dan pajak Bea Balik Nama Kendaraan Bermotor (BBNKB) pada Kantor Bersama SAMSAT Denpasar. E-Jurnal Akuntansi Universitas Udayana, 6 (1), hal. 340-353.

Feld, Lar P.and Bruno S. Frey. 2002. Trust breed trust: how taxpayers are treated. Journal economics of governance, 3, pp.87-99.

Fikriningrum, Winda Kurnia. 2012. Analisis Faktor-Faktor yang Mempengaruhi Wajib Pajak Orang Pribadi dalam Memenuhi Kewajiban Membayar Pajak. Semarang: Universitas Diponegoro.

Fuadi, Arabella O. dan Yenni Mangonting. 2013. Pengaruh Kualitas Pelayanan Petugas Pajak, Sanksi Perpajakan, dan Biaya Kepatuhan Pajak terhadap Kepatuhan Wajib Pajak UMKM. Tax \& Accounting Review, 1 (1), hal: $18-27$

Fronzoni, A. Luigi. 1999. Tax Evation and TaxCompliance. Italy: University of Bologna.

Ghozali, Imam. 2013. Aplikasi Analisis Multivariate dengan Program SPSS, Edisi 7. Semarang: Universitas Diponogoro. 
Green, L. 1991. Precede-Proceed Framework. Colombia: My Field Publishing Company.

Hair, J.F., et al. 1995. Multifariate Data Analisis With Readings, 4. Englewood Cliffs, NJ : Prentice Hall.

Hardiningsih, Panca danNila Y.2011.Faktor-Faktor Yang Memengaruhi Kemauan Membayar Pajak. Jurnal Dinamika Keuangan dan Perbankan,3(1), hal.126-142.

Laksono, Jati Purbo dan Moch. Didik Ardiyanto. 2011. Analisis Faktor-Faktor yang Memengaruhi Kepatuhan Wajib Pajak Badan pada Perusahaan Industri Manufaktur di Semarang. Diponegoro Journal of Accounting.

Lederman, Leandra.2003. The Interrplay Betwen Norms and Enforcement in TaxCompliance. Ohio State Law Journal,64(6),pp.1453-1514.

Mardiasmo.2013. Perpajakkan Edisi Revisi. Yogyakarta: Andi.

Mustikasari, Elia. 2007. Kajian Empiris tentang Kepatuhan Wajib Pajak Badan di Perusahaan Industri Pengolahan di Surabaya. Simposium Nasional Akuntansi X.

Palda, F. dan J. Hanosek.2002. Journal Quality of Government Services and the Civic Duty to Pay Taxes in the Czech and Slovak Republics, and other Transision Countries.

Palil, M Rizal.2005. Does TaxKnowledge Matter in SelfAssessment System Evidence from Malaysia Tax Administrative. Journal of American Academic of Business Cambrige. No 2.

Paramartha, I Putu I. P.2015. Pengaruh Kaulitas Pelayanan, Pengetahauan, dan Sanksi Perpajakan pada Kepatuhan Wajib Pajak Badan di KPP Pratama Gianyar. Skripsi. Sarjana Jurusan Akuntansi Fakultas Ekonomi dan Bisnis Universitas Udayana, Bali.

Parasuraman, et al. 1985. A Conceptual Model of Service Quality Its Implication Future Research. Journal of Marketing, 49, pp.41-50

Pranata, Putu Aditya dan Putu Ery Setiawan. 2015. Pengaruh Sanksi Perpajakan, Kualitas Pelayanan, dan Kewajiban Moral pada Kepatuhan Wajib Pajak. E-Jurnal Akuntansi Universitas Udayana, 10 (2), hal.456-474. 
Putri, Siswanto A. R.A dan I Ketut Jati.2012.Faktor-faktor yang Memengaruhi Kepatuhan Wajib pajak dalam Membayar Pajak Kendaraan Bermotor di Kantor SAMSAT Denpasar. E-Jurnal Akuntansi Fakultas Ekonomi dan Bisnis Universitas Udayana, 2 (3).

Redae, Redae Berhe dan Shailinder Sekhon. 2017. Taxpayers' Moral and Compliance behavioral in Ethiopoa: A study of Tigray state. International Journal of Research in Finance and Marketing (IJRFM), 7 (4), pp.109-123.

Richardson, G. 2006. The Impact of Tax Fairness Dimensions on Tax Compliance Behaviour in an Asean Jurisdiction: The Case of Hong Kong. The International Tax Journal,32(1), pp.29-42.

Rusmayani, Ni Made Lisa dan Luh Supadmi. 2017. Pengaruh Sosialisasi, Pengetahuan, Sanksi, dan Kualitas Pelayanan pada Kepatuhan Wajib Pajak Kendaraan Bermotor. Skripsi. Sarjana Jurusan Akuntansi Fakultas Ekonomi dan Bisnis Universitas Udayana, Bali

Rusyadi M. K., 2009.Dampak Persepsi Tangung Jawab Perusahaan pada Tax Planning. Jurnal Akuntansi dan Bisnis,9(1),hal. 61-70.

Sanjaya, I Putu A. P. 2015. Pengaruh Kualitas Pelayanan, Kewajiban Moral, dan Sanksi Perpajakan pada Kepatuhan Wajib Pajak dalam Membayar Pajak Hotel di Dinas Pendapatan Kota Denpasar. E-Journal Akuntansi Universitas Udayana, 7 (1), hal.207-222.

Siregar, S. dan Listyorini. 2012. Pengaruh Pelayanan Fiskus dan Pengetahuan Perpajakan Terhadap Kepatuhan Wajib Pajak. Jurnal Ilmu Administrasi Bisnis, 1 (1), hal. 1-9.

Slemrod, R. 1991. Did the Tax Act of 1986 Simplity Tax Matter. The Journal of Economic Prospective.6(1), pp: 45-57

Sucahyani, Ni Made Arum. 2017. Penggaruh Pengetahuan Perpajakkan, Pelayanan Fiskus, Biaya Kepatuhan Pajak, dan Sanksi Perpajakan pada Kepatuhan Wajib Pajak dalam Membayar Pajak Hotel di Dinas Pendapatan Kabupaten Tabanan. Skripsi. Sarjana Jurusan Akuntansi Fakultas Ekonomi dan Bisnis Universitas Udayana, Bali.

Sugiyono. 2015. Metoda Penelitian Pendidikan. Bandung: Alfabeta.

Susmita, Putu R. 2015. Pengaruh Kualitas Pelayanan, Sanksi Perpajakan, Biaya Kepatuhan, dan Penerapan E-Filing Pada Kepatuhan Pelaporan WPOP di Kantor Pelayanan Pajak Pratama Denpasar Timur. Skripsi. Sarjana Jurusan Akuntansi Fakultas Ekonomi dan Bisnis Universitas Udayana, Bali. 
Torgler, B. 2005. Direct Democracy and Tax Morale. European Journal of Political Economic,21(3),pp.525-531.

Utama, I Waayan M. 2013. Pengaruhkualitas Pelayanan, Sanksi Perpajakkan dan Biaya Kepatuhan pada Kepatuhan Wajib Pajak. E- Jurnal Akuntansi Ekonomi dan Bisnis Universitas Udayana,2(2).

Utomo, Banyu A.W. 2011. Pengaruh Sikap, Kesadaran Wajib Pajak dan Pengetahuan Perpajakan Terhadap Kepatuhan Wajib Pajak Dalam Membayar PBB di Kecamatan Pemulang Kota. 